\title{
The Plasmin System Is Induced by and Degrades Amyloid- $\beta$ Aggregates
}

\author{
H. Michael Tucker, ${ }^{1}$ Muthoni Kihiko, ${ }^{1}$ Joseph N. Caldwell, ${ }^{1}$ Sarah Wright, ${ }^{5}$ Takeshi Kawarabayashi, ${ }^{4}$ \\ Douglas Price, ${ }^{2}$ Donald Walker, ${ }^{5}$ Stephen Scheff, ${ }^{2}$ Joseph P. McGillis, ${ }^{3}$ Russell E. Rydel,, 5 and Steven Estus ${ }^{1}$
}

\author{
${ }^{1}$ Department of Physiology, ${ }^{2}$ Department of Anatomy and Neurobiology, Sanders-Brown Center on Aging, and \\ ${ }^{3}$ Department of Microbiology and Immunology, University of Kentucky, Lexington, Kentucky 40536, 4 Mayo Clinic, \\ Jacksonville, Florida 32224, and 5Elan Pharmaceuticals, Inc., South San Francisco, California 94080
}

\begin{abstract}
Amyloid- $\beta(A \beta)$ appears critical to Alzheimer's disease. To clarify possible mechanisms of $A \beta$ action, we have quantified $A \beta$-induced gene expression in vitro by using $A \beta$-treated primary cortical neuronal cultures and in vivo by using mice transgenic for the $A \beta$ precursor $(A \beta P)$. Here, we report that aggregated, but not nonaggregated, $A \beta$ increases the level of the mRNAs encoding tissue plasminogen activator (tPA) and urokinase-type plasminogen activator (UPA). Moreover, tPA and uPA were also upregulated in aged $A \beta P$ overexpressing mice. Because others have reported that $A \beta$ aggregates can substitute for fibrin aggregates in activating tPA post-translationally, the result of $t P A$ induction by $A \beta$ would be cleavage of plasminogen to the active protease plasmin. To gain insights into the possible actions of plasmin, we evaluated the hypotheses
\end{abstract}

Neocortical $\mathrm{A} \beta$ deposits are a hallmark of Alzheimer's disease (AD). That $\mathrm{A} \beta$ accumulation is critical to $\mathrm{AD}$ is suggested by findings that mutations in several genes associated with familial $\mathrm{AD}$ (FAD) increase amyloidogenic $\mathrm{A} \beta$ production (for review, see Selkoe, 1997; Price and Sisodia, 1998). In sporadic AD, increased $\mathrm{A} \beta$ may result from enhanced $\mathrm{A} \beta$ production, which has been the subject of intense scrutiny, or from decreased $\mathrm{A} \beta$ clearance, which has been studied relatively little.

Although the plasmin proteolytic cascade is traditionally considered in terms of fibrinolysis and cell migration, the plasmin system may also be relevant to $\mathrm{A} \beta$ clearance. The principal components of this system include plasminogen/plasmin, tissue plasminogen activator (tPA), urokinase-type plasminogen activator (UPA), plasminogen activator inhibitor (PAI-1), and $\alpha-2-$ antiplasmin ( $\alpha 2$-AP) (for review, see Henkin et al., 1991; Reuning et al., 1998). This proteolytic cascade begins with localized synthesis and secretion of tPA and uPA. After post-translational activation, tPA and UPA cleave plasminogen to yield the active serine protease plasmin, which then proteolyzes its target proteins. The activity of plasminogen activators and plasmin is kept highly localized by their primary inhibitors, PAI- 1 and $\alpha 2$-AP,

\footnotetext{
Received Feb. 4, 2000; accepted March 6, 2000.
}

This work was supported by grants from the American Health Assistance Foundation and National Institutes of Health Grant NS-35607 (S.E.), as well as the French Foundation for Alzheimer's Disease (H.M.T.). We thank Richard Kyruscio for statistical analysis and Pamela S. Keim for help with the mass spectral analysis of $\mathrm{A} \beta$ fragments. We also thank Steven Younkin for helpful discussion.

M.T., T.K., and S.E. conducted the studies using the $\mathrm{A} \beta \mathrm{P}$ transgenic mice.

Correspondence should be addressed to Drs. H. Michael Tucker or Steven Estus, 800 South Limestone, Lexington, K Y 40536-0230. E-mail: mtucker@pop.uky.edu or sestus@aging.coa.uky.edu.

Copyright $\odot 2000$ Society for Neuroscience $0270-6474 / 00 / 203937-10 \$ 15.00 / 0$ that tPA and plasmin may mediate $A \beta$ in vitro toxicity or, alternatively, that plasmin activation may lead to $A \beta$ degradation. In evaluating these conflicting hypotheses, we found that purified plasmin degrades $A \beta$ with physiologically relevant efficiency, i.e., $\sim 1 / 10$ th the rate of plasmin on fibrin. Mass spectral analyses show that plasmin cleaves $A \beta$ at multiple sites. Electron microscopy confirms indirect assays suggesting that plasmin degrades $A \beta$ fibrils. Moreover, exogenously added plasmin blocks $\mathrm{A} \beta$ neurotoxicity. In summation, we interpret these results as consistent with the possibility that the plasmin pathway is induced by aggregated $A \beta$, which can lead to $A \beta$ degradation and inhibition of $A \beta$ actions.

Key words: amyloid; plasmin; tissue plasminogen activator; apoptosis; gene induction; Alzheimer's disease; proteolysis

respectively. In fibrinolysis, tPA binds to fibrin aggregates, leading to a conformational change in tPA that dramatically increases its affinity for plasminogen, resulting in proteolytic cleavage of plasminogen to active plasmin. Recent work has shown that $\mathrm{A} \beta$ aggregates can substitute for fibrin aggregates in activating tPA (Kingston et al., 1995; Wnendt et al., 1997), suggesting that tPA may be activated by $\mathrm{A} \beta$ in $\mathrm{AD}$.

The role of the plasmin system in neuronal death is under intense scrutiny. In the brain, tPA, uPA, and plasminogen are synthesized in neurons, and tPA is synthesized by microglia as well (Tsirka et al., 1997). In ischemia and excitotoxicity models, tPA induction and subsequent plasmin generation have been implicated in neuronal loss (Chen and Strickland, 1997; Tsirka et al., 1997; Wang et al., 1998). This neuronal loss may be induced by extracellular matrix degradation because plasmin may degrade laminin directly or indirectly by activation of extracellular metalloproteases (Lijnen et al., 1998). Indeed, matrix degradation has been implicated in apoptosis in vitro (Basbaum and Werb, 1996) and stroke (Romanic et al., 1998). However, the neurotoxic role of the plasmin system has been challenged by reports that direct tPA infusion does not cause neuronal loss (Tsirka et al., 1996) and, moreover, that tPA may be directly neuroprotective in excitotoxicity models both in vitro and in vivo (Kim et al., 1999).

Here, we evaluate the role of the plasmin system in the cellular response to $\mathrm{A} \beta$. We report that $\mathrm{A} \beta$ accumulation induces $t P A$ and $u P A$ expression in vitro and in vivo. Whether the product of tPA action, plasmin, is neurotoxic by degrading neuronal extracellular proteins, or neuroprotective by degrading $A \beta$, was evaluated by quantifying plasmin-mediated $\mathrm{A} \beta$ degradation and modulation of $\mathrm{A} \beta$ neurotoxicity. Our results indicate that plasmin degrades $\mathrm{A} \beta$ 
and blocks $\mathrm{A} \beta$ toxicity. We discuss the potential physiological and therapeutic implications of these results.

\section{MATERIALS AND METHODS}

Primary rat cortical neuron preparations. Primary rat cortical neuron cultures were established from embryonic day 18 (E18) rat fetuses as described previously (Estus et al., 1997). Briefly, cell suspensions were plated at $0.75-1.25 \times 10^{5}$ cells per polyethyleneimine-coated $6.4 \mathrm{~mm}$ well in $100 \mu \mathrm{l}$ of DMEM/B27 (Life Technologies, Rockville, MD) supplemented with $100 \mathrm{U} / \mathrm{ml}$ penicillin, $100 \mu \mathrm{g} / \mathrm{ml}$ streptomycin, and B27 (Life Technologies). Cells were plated onto either 96 well microtiter plates or 16 well chamber slides (Nalge Nunc International, Rochester, NY). Serum replacement with B27 supplement yields nearly pure neuronal cultures as judged by immunocytochemistry for glial fibrillary acidic protein (GFAP) and neuron-specific enolase (NSE) (Brewer et al., 1993).

Neuronal treatments. Neuronal preparations were treated with A $\beta 1-40$ in the presence or absence of plasmin as indicated. For experiments involving aggregated $\mathrm{A} \beta$, stock $\mathrm{A} \beta$ solutions (lot number ZK840; Bachem, Torrance, CA; or lot number MF-0641; California Peptide Research, Napa, CA) (1 mM) were prepared in sterile, double-distilled water and frozen at $-80^{\circ} \mathrm{C}$ until use. For experiments comparing aggregated and nonaggregated $\mathrm{A} \beta$ treatments, $\mathrm{A} \beta 1-40$ (lot number ZM605; Bachem) was either prepared as above (aggregated) or dissolved to 7.5 $\mathrm{mM}$ in dimethylsulfoxide (DMSO), sonicated for $30 \mathrm{~min}$ in a bath sonicator, and filtered through a $3 \mathrm{~mm}$ Teflon membrane filter (pore size, $0.2 \mu \mathrm{m}$ ) (nonaggregated). Purified human plasmin (American Diagnostica, Greenwich, CT) was dissolved in $100 \mathrm{~mm}$ Tris, $\mathrm{pH}$ 7.4, 0.1\% Tween 20, $0.1 \mathrm{~mm}$ EDTA, and 20\% glycerol to generate stock solutions. These were then aliquoted and stored at $-80^{\circ} \mathrm{C}$ until use. After initially observing lot-to-lot variation in the plasmin-specific activity, all plasmin was subsequently normalized to the manufacturer's indicated plasmin specific activity, i.e., because $20 \mu \mathrm{g}$ of active plasmin should generate a colorimetric change of $0.2 \mathrm{AU} / \mathrm{min}$ in a standard reaction containing 0.1 $\mathrm{mm}$ Spectrozyme-PL, we used plasmin protein sufficient to generate this amount of Spectrozyme-PL conversion, and considered this equivalent to $20 \mu \mathrm{g}$ of active plasmin.

Rat cortical neurons cultured $2 \mathrm{~d}$ in vitro were exposed to $\mathrm{A} \beta$ by removing the culture medium and replacing it with DMEM supplemented with $100 \mathrm{U} / \mathrm{ml}$ penicillin, $100 \mu \mathrm{g} / \mathrm{ml}$ streptomycin, and $\mathrm{N} 2 \mathrm{me}-$ dium supplement (Life Technologies). A $\beta$ and plasmin, alone or in the indicated combinations, was then added to the indicated final concentrations. Experiments involving plasmin pretreatment were initiated on neurons after $1 \mathrm{~d}$ in vitro. For experiments involving DMSO solvated, nonaggregated $\mathrm{A} \beta$, possible solvent-confounding effects were minimized by adding an equal volume of DMSO to control and aggregated $\mathrm{A} \beta$ treated wells such that the final DMSO concentrations were equivalent in all samples.

Neurotoxicity assays. After the indicated treatments, neuronal cultures were maintained for $48 \mathrm{hr}$ before neuronal survival was assessed by scoring for chromatin condensation by an observer "blinded" as to the cellular treatments. Briefly, neurons were fixed with $4 \%$ paraformaldehyde, rinsed with PBS, stained with Hoechst 33258 at $1 \mu \mathrm{g} / \mathrm{ml}$ in PBS for $10 \mathrm{~min}$, and chromatin then visualized by fluorescence microscopy. Neurons manifesting condensed chromatin were scored as "apoptotic" whereas those with uniformly distributed chromatin were scored as "normal". At least 250 neurons were scored in each well of 16 well chamber slides, and experiments were typically performed in triplicate. Where indicated, statistical analysis was performed in consultation with the Sanders-Brown Center on Aging Biostatistics Core; a mixed linear model was used with random effects caused by replicates, replicates by treatment combination, and individual treatments. Post hoc analysis was by Fisher's PLSD procedure on least squares means produced by the mixed linear model to account for incomplete blocks and on Satterthwaite's procedure for estimating the degrees of freedom. Computations were done by using the Statistical Analysis System (Littell et al., 1996).

Chromatin fragmentation was assessed by using a fluorescent DNA end-labeling technique, i.e., terminal deoxynucleotidyl transferasemediated biotinylated UTP nick end labeling (TUNEL), as described previously (Estus et al., 1997).

Murine model of $A \beta$ accumulation. Three mice transgenic for the human $\mathrm{A} \beta$ precursor protein $(\mathrm{A} \beta \mathrm{P})$ (Hsiao et al., 1996) and three strain-matched (C57B6/SJL) control mice were maintained for equivalent periods, i.e., $22 \pm 2$ months (mean $\pm \mathrm{SD}$ ). After euthanasia, their brains were rapidly removed and flash-frozen in liquid nitrogen.

Gene expression assays. For the analyses of gene expression in vitro, total RNA was purified and reverse-transcribed as described previously (Estus et al., 1997). For the analyses of gene expression in vivo, total RNA was isolated from one cortical hemisphere (Chomczynski and Sacchi, 1987), and $1 \mu \mathrm{g}$ aliquots were subjected to reverse transcription. Gene expression was analyzed by using PCR to incorporate radioactive tracer into cDNA corresponding to specific mRNAs, as described and validated previously (Estus, 1997; Estus et al., 1997). After amplification, the cDNAs were separated by PAGE and visualized and quantified by phosphorimaging technology (Fuji, Stamford, CT). Differences between mouse brain samples were analyzed by a Student's $t$ test (StatView; Abacus Concepts, Calabasas, CA).

The primer sequences used in this study were either reported previously (Estus et al., 1997) or were: $t P A$ sense primer: 5' GGGCTCTGACTTCGTSTGCC $3^{\prime}, t P A$ antisense primer: 5' CCTTGCACTGTAGGGCTTCTA $3^{\prime}$ (185 bp product); $u P A$ sense primer: 5' CTCTTACCGAGGAAAGGCCA $3^{\prime}, u P A$ antisense primer: 5' TGTCGGGGTTCCTGCAGTAA 3'(151 bp product); timp1 sense primer: 5' GAAATCATCGAGACCACCTT 3', timp1 antisense primer: 5' AACCGGATATCTGTGGCATT 3' (97 bp product); timp2 sense primer: 5' CCCTGTGACACGCTTAGCAT 3', timp2 antisense primer: 5' TGGTGCCCATTGATGCTCTT 3' (166 bp product); timp3A sense primer: 5' GCCTCAAGCTAGAAGTCAA $3^{\prime}$, and timp $3 A$ antisense primer: 5' TGTGAGGTGGTCCCACCTCT 3' (109 bp product). The identity of the amplified cDNAs was confirmed by direct sequencing.

Immunofluorescence. The integrity of the neuronal cytoskeleton was visualized by anti-neurofilament immunofluorescence. Neurons were treated as indicated, fixed with $4 \%$ paraformaldehyde, and permeabilized with $0.05 \%$ Triton X-100 in PBS. Nonspecific antibody binding was then blocked with 5\% goat serum in PBS, and neurofilaments labeled with a cocktail of anti-neurofilament $\mathrm{L}, \mathrm{M}$, and $\mathrm{H}$ monoclonal antibodies (purchased individually from Sigma, St. Louis, MO) diluted in blocking buffer $(1 / 250)$. Primary antibodies were then visualized with a Cy3conjugated secondary antibody (Jackson ImmunoResearch, West Grove, PA). After counterstaining with Hoechst 33258, cells were examined by fluorescence microscopy.

Analysis of $A \beta$ degradation. To assay $\mathrm{A} \beta$ proteolysis, solutions of $\mathrm{A} \beta$ and plasmin, prepared as described above, were incubated at $37^{\circ} \mathrm{C}$ in a 25 $\mu \mathrm{l}$ reaction volume containing $100 \mathrm{~mm}$ Tris, $\mathrm{pH} 7.4,0.1 \%$ Tween 20 , and $0.1 \mathrm{~mm}$ EDTA, as we described previously for other plasmin substrates (Tucker et al., 1995). At the end of the incubation, the reaction was stopped by the addition of $25 \mu \mathrm{l}$ of $0.1 \%$ trifluoroacetic acid (TFA) and frozen on dry ice. Intact $\mathrm{A} \beta$ was then detected and quantified by HPLC methodology. Briefly, $25 \mu \mathrm{l}$ aliquots of the stopped reaction volumes were loaded onto a C18 reverse-phase HPLC column (Vydac, Hisperia, CA) in $2 \%$ acetonitrile, $0.1 \%$ TFA, and eluted with an acetonitrile gradient (2-55\% over $30 \mathrm{~min}$ ). Peptides were detected and quantified by absorbance at $215 \mathrm{~nm}$. Kinetics were analyzed as we described previously (Vijayaragahaven et al., 1995); Kcat values were determined from the time required for plasmin to reduce $\mathrm{A} \beta$ levels by $50 \%$. The identity of the $\mathrm{A} \beta$ degradation fragments was determined by using matrix-assisted laser desorption ionization time-of-flight mass spectrometry (Ciphergen Biosystems, Palo Alto, CA) to analyze HPLC-purified $\mathrm{A} \beta$ fragments.

Electron microscopy. A $\beta$-containing solutions $(100 \mu \mathrm{M})$ were allowed to aggregate for $6 \mathrm{hr}$ at $37^{\circ} \mathrm{C}$ and then analyzed directly or treated with plasmin ( $70 \mathrm{~nm}$ ) for $6 \mathrm{hr}$, as described above. For electron microscopy, 0.5 $\mu l$ of $A \beta$-containing solution was applied to a formvar-carbon-coated copper grid, allowed to dry, and stained with $2 \%$ uranyl acetate. The aggregates were then visualized on a Zeiss 902 electron microscope at 80 $\mathrm{kV}$. Similar results were obtained when samples were fixed with a $1 \%$ glutaraldehyde and $4 \%$ paraformaldehyde mixture before application to the grid. Magnification was determined by reference to a standard calibration grid (Ted Pella, Redding, CA) that was imaged and photographed in parallel with the $\mathrm{A} \beta$ samples.

\section{RESULTS}

\section{Aggregated but not nonaggregated $A \beta$ induces $t P A$, $u P A$, and timp1 in vitro}

To begin to evaluate the hypothesis that $\mathrm{A} \beta$-induced gene expression may modulate the extracellular proteolytic milieu, we quantified $\mathrm{A} \beta$ effects on the expression of several relevant genes. $\mathrm{A} \beta$ effects were analyzed in an in vitro model of $\mathrm{A} \beta$ neurotoxicity described previously (Estus et al., 1997). In this model, primary cortical neurons treated with $\mathrm{A} \beta(20 \mu \mathrm{M})$ begin to undergo 
A

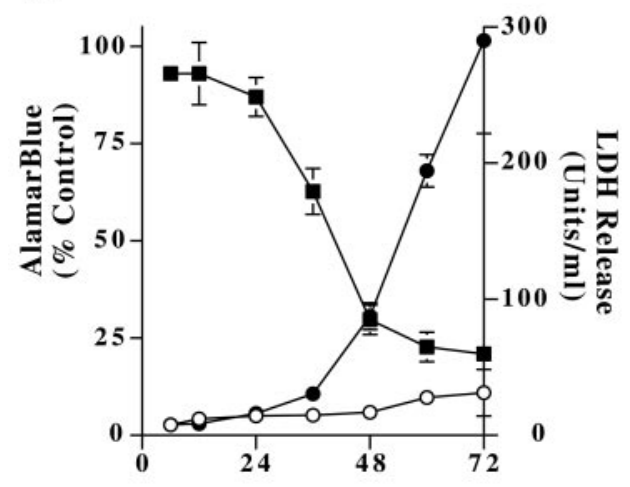

Duration of AB Treatment (hrs)

$\longrightarrow$ AB1-40 (alamarBlue, \% Control)

$\longrightarrow$ Control (LDH released, Units $/ \mathrm{ml}$ )

$\longrightarrow$ AB1-40 (LDH released, Units/ml)

C
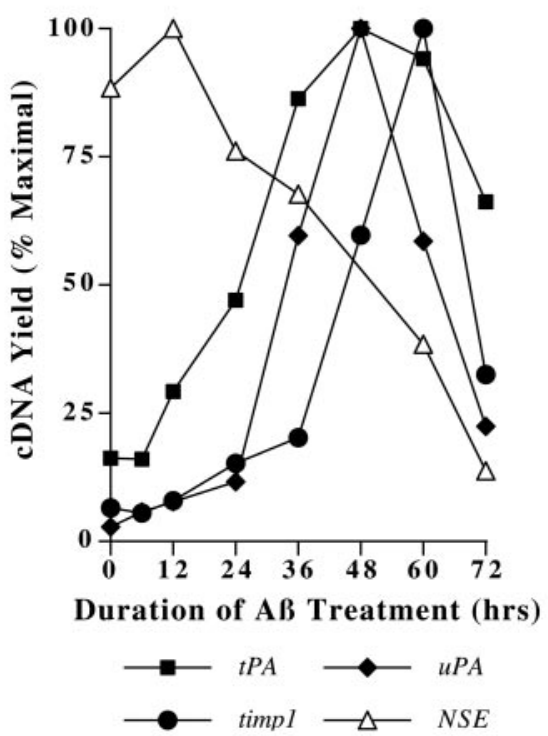

B tPA

UPA

TIMP1

TIMP2

TIMP3A

NSE

MAP-2

D

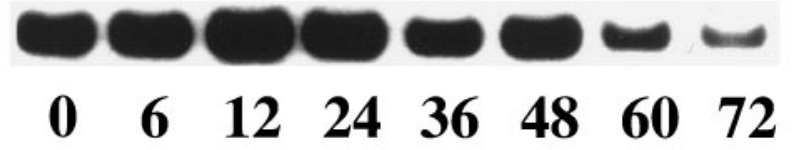

\section{Duration of Amyloid Treatment (hrs)}

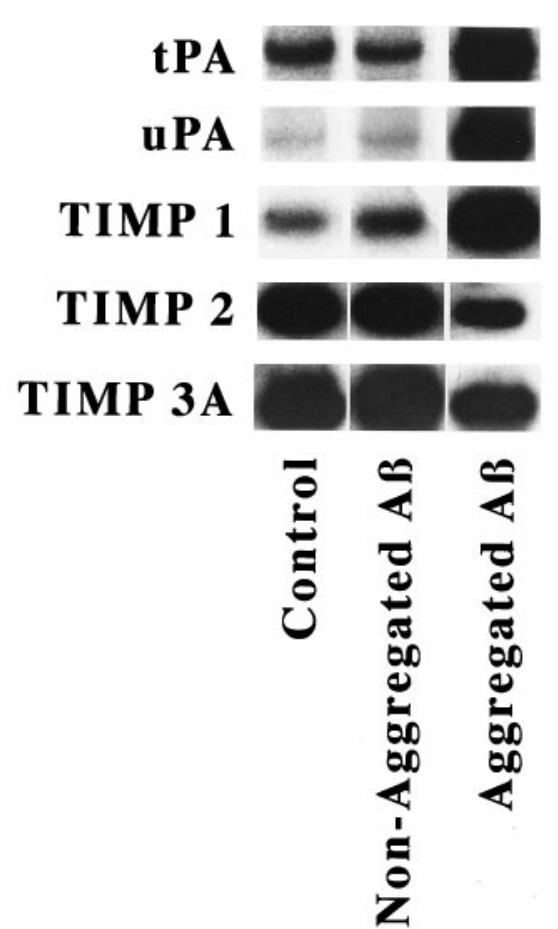

Figure 1. Selective gene induction accompanies A $\beta$ toxicity. Rat cortical neurons were treated with A $\beta 1-40$ (20 $\mu \mathrm{M}$, lot number ZK840) for the indicated intervals, and cell viability was assayed by AlamarBlue reduction and LDH release ( $A$, reprinted with permission from Estus et al., 1997$)$. $t P A$, $u P A$, and timp1 are induced by $\mathrm{A} \beta$ treatment $(B)$. RNA was isolated from neurons treated in parallel with those depicted in $A$, and changes in gene expression were analyzed by RT-PCR. Results from this representative experiment are depicted graphically $(C)$. These gene inductions occur only in cultures treated with aggregated $\mathrm{A} \beta(D)$. Each of these experiments were confirmed in at least two separate neuronal preparations.

apoptosis after $36 \mathrm{hr}$ of treatment (Fig. 1A). Previously, we and others reported that $\mathrm{A} \beta$ markedly induces the mRNA encoding the extracellular matrix protease transin (MMP-9) (Deb and Gottschall, 1996; Estus et al., 1997), and others reported that A $\beta$ induces MMP-2 as well (Deb and Gottschall, 1996).
Because $\mathrm{A} \beta$ treatment leads to $c$-jun induction beginning at 12 hr (Estus et al., 1997), and $t P A$ is known to be induced by c-Jun (Arts et al., 1997), we began by quantifying $\mathrm{A} \beta$ effects on $t P A$ and the related $u P A$. To evaluate the balance in the extracellular proteolytic milieu, we also quantified three mRNAs that encode 
tissue inhibitors of matrix proteases (TIMP), including timp1, timp2, and timp3a. RNA was prepared from cells treated in parallel with those described in Figure $1 A$ and changes in gene expression quantified by RT-PCR (Fig. $1 B, C$ ). As we described previously (Estus et al., 1997), A $\beta$ treatment causes a generalized decrease in mRNAs unique to neurons, including NSE and map-2. In contrast to these declining patterns of expression, $\mathrm{A} \beta$-treatment induced $t P A$, beginning with $12 \mathrm{hr}$ of treatment, as well as $u P A$ and timpl, beginning at 36 and $48 \mathrm{hr}$, respectively (Fig. $1 B, C$ ). As neuronal membrane integrity was breached, especially at $72 \mathrm{hr}$, each of the mRNAs declined. $t P A$ was induced roughly concurrent with $c$-jun, whereas $u P A$ and timpl were induced well after $c$-jun (Estus et al., 1997), consistent with the possibility that c- Jun may contribute to their induction. In contrast to the robust upregulation of $t P A, u P A$, and timp1, the mRNAs encoding TIMP 2 and TIMP3A were unchanged by $\mathrm{A} \beta$ treatment, suggesting a degree of specificity in these gene inductions.

Because $\mathrm{A} \beta$ neurotoxicity depends on the ability of $\mathrm{A} \beta$ to aggregate (Pike et al., 1991; Simmons et al., 1994; Estus et al., 1997), we next compared the abilities of aggregated and nonaggregated $\mathrm{A} \beta$ to regulate gene expression. $\mathrm{A} \beta$ was solvated in either water (to promote subsequent aggregation) or DMSO (to inhibit subsequent aggregation), and then diluted into medium and used to treat cells. DMSO was added to the water-solvated $\mathrm{A} \beta$ such that the final DMSO concentration was equivalent between the two $\mathrm{A} \beta$ treatments. After $48 \mathrm{hr}$ of treatment, the water-solvated $\mathrm{A} \beta$ had induced a dramatic decrease in cellular viability, as assessed by AlamarBlue reducing potential, which declined to $15.4 \pm 1.0 \%$ of vehicle-treated control neuronal preparations (mean $\pm \mathrm{SD} ; n=3$ ). In contrast, DMSO-solvated $\mathrm{A} \beta$ did not alter AlamarBlue reduction significantly from vehicletreated controls $(99.7 \pm 2.9 \%$ of control; mean $\pm \mathrm{SD} ; n=3$; Estus et al., 1997). Examination of gene expression in neurons treated in parallel showed that aggregated, but not nonaggregated, $\mathrm{A} \beta$ treatment led to the induction of $t P A, u P A$, and timp1 (Fig. $1 D$ ). In summary, $t P A, u P A$ and timpl were induced by $\mathrm{A} \beta$ in a time- and aggregation-dependent fashion.

\section{A $\beta$ accumulation correlates with tPA and uPA induction in vivo}

To evaluate whether the plasmin system may also be activated by $\mathrm{A} \beta$ accumulation in vivo, we quantified the expression of $t P A$ and $u P A$ in mice transgenic for $\mathrm{A} \beta \mathrm{P}$ expression (Hsiao et al., 1996). RNA was isolated from $\mathrm{A} \beta$-overproducing mice or from congenic control mice of equivalent age. We first quantified the expression of actin and pgp9.5, which are expressed constitutively by all cells and by neurons, respectively (Fig. $2 A$ ). The expression of these genes was equivalent among the various samples. We next quantified the expression of GFAP, an mRNA upregulated in reactive astrocytes described in these mice (Hsiao et al., 1996). The mRNA encoding GFAP was increased nearly twofold in the $\mathrm{A} \beta$ producing mice (Fig. $2 A, B ; p<0.005$; Student's $t$ test). We then quantified the expression of the mRNAs encoding tPA and uPA. Each of these mRNAs was also increased significantly in the $\mathrm{A} \beta$-overproducing mice (Fig. $2 A, B ; p<0.04$ ). Hence, $\mathrm{A} \beta$ accumulation in vivo is also associated with increased $t P A$ and $u P A$ expression.

\section{Plasmin efficiently degrades $A \boldsymbol{\beta}$}

Because the active protease plasmin results from $\mathrm{A} \beta$-inducing tPA expression as well as activating tPA post-translationally (Kingston et al., 1995; Wnendt et al., 1997), and because plasmin
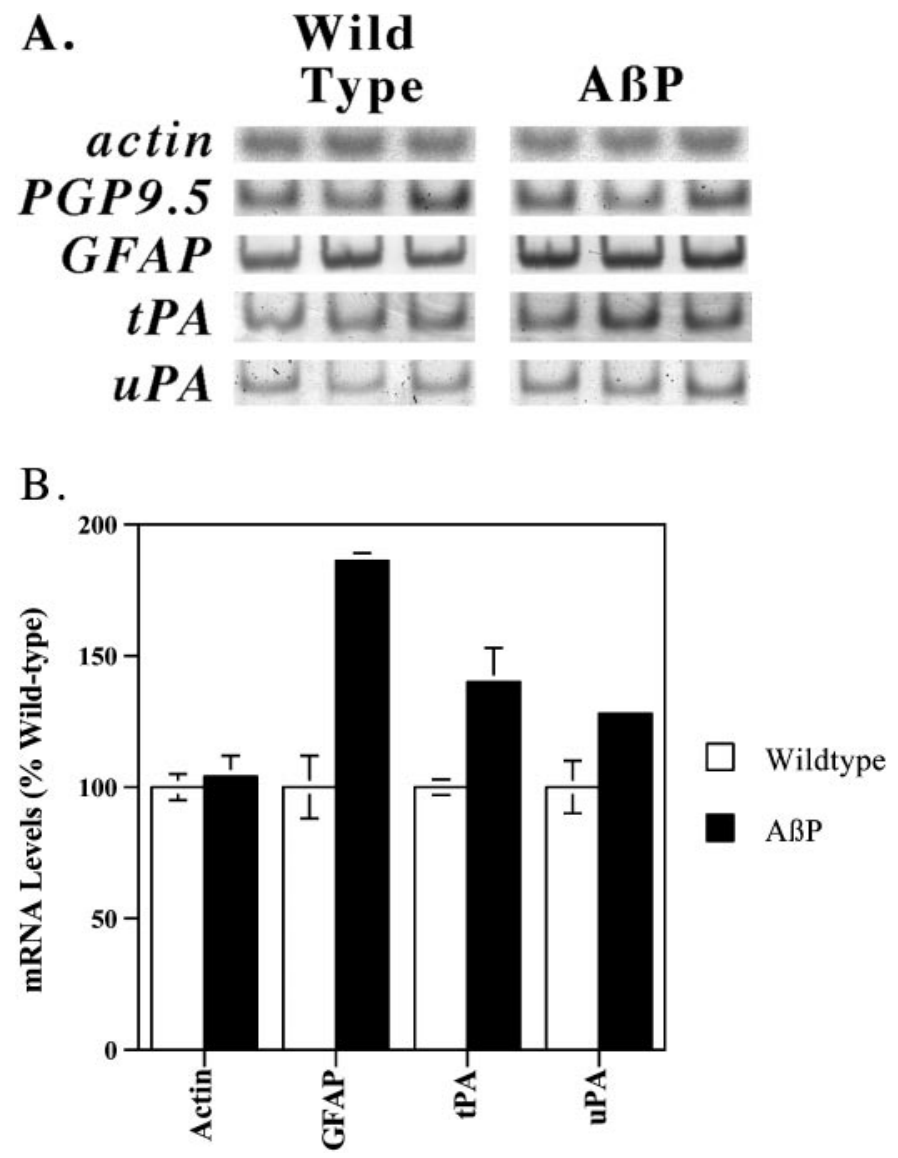

Figure 2. $t P A$ and $u P A$ are induced by $\mathrm{A} \beta$ accumulation in vivo. Aged mice transgenic for $\mathrm{A} \beta \mathrm{P}$ expression or matched control mice were killed, and their brains were analyzed for altered gene expression by RT-PCR. The results are presented both as autoradiographs $(A)$ and, for selected genes, graphically (mean $\pm \mathrm{SE}, n=3)(B)$. Equivalent results were obtained in two separate PCR analyses of these samples.

is known to degrade another aggregated protein and tPA cofactor, fibrin (Henkin et al., 1991), we hypothesized that plasmin may degrade $\mathrm{A} \beta$. Therefore, we established an assay for $\mathrm{A} \beta$ clearance wherein the ability of purified human plasmin to degrade $\mathrm{A} \beta 1-40$ was monitored by using reverse-phase HPLC to separate $\mathrm{A} \beta$ fragments, which were then detected by UV absorbance. Figure 3 shows chromatograms reflecting freshly solvated $\mathrm{A} \beta(40 \mu \mathrm{M})$ that was incubated $30 \mathrm{~min}$ in the absence (Fig. $3 A$ ) or presence of plasmin ( $70 \mathrm{~nm}$; Fig. $3 B$ ). Plasmin cleaves $A \beta$, as discerned by the disappearance of $\mathrm{A} \beta$ and the appearance of eight new peaks (plasmin is not detectable at these concentrations, and elutes after $\mathrm{A} \beta$ when added in excess). The identity of these peaks was determined by mass spectral analysis (Table 1); each fragment is consistent with the known specificity of plasmin to cleave after the basic amino acids lysine or arginine. These results confirm and dramatically extend those of others (Van Nostrand and Porter, 1999), who reported quite recently that plasmin degrades $\mathrm{A} \beta$ largely at position five, i.e., the predominant fragment was DAEFR. The more complete $\mathrm{A} \beta$ degradation that we report here may reflect that we standardized the purified plasmin relative to a synthetic colorimetric plasmin substrate, and hence may have used a higher level of active plasmin than others (Van Nostrand and Porter, 1999).

We next examined the plasmin concentration dependence of $\mathrm{A} \beta$ cleavage. $\mathrm{A} \beta(40 \mu \mathrm{M})$ was incubated with increasing concen- 



Figure 3. Plasmin proteolyzes $\mathrm{A} \beta$ into multiple fragments. These HPLC chromatograms depict $\mathrm{A} \beta(40 \mu \mathrm{M})$ treated without $(A)$ or with $(B)$ plasmin $(70 \mathrm{~nm})$ for $30 \mathrm{~min}$ at $37^{\circ} \mathrm{C}$. After the reaction was stopped, the proteins were separated by $\mathrm{C} 18$ reverse-phase HPLC, and $\mathrm{A} \beta$ fragments were detected by their absorbance at $215 \mathrm{~nm}$.

trations of plasmin (0-160 nM) for $30 \mathrm{~min}$, and the amount of remaining $\mathrm{A} \beta 1-40$ was quantified. These data, shown in Figure $4 A$, indicate that plasmin degrades $\mathrm{A} \beta$ in a concentrationdependent manner. Although plasminogen is synthesized constitutively in CNS neurons (Tsirka et al., 1997), CSF concentrations of plasminogen have not been reported. However, these plasmin concentrations used here are much less than the reported serum plasminogen concentration of $2 \mu \mathrm{M}$ (Kwaan, 1992).

We proceeded to examine the time course of $\mathrm{A} \beta$ clearance by plasmin (Fig. $4 B)$. A $\beta 1-40(40 \mu \mathrm{M})$ and plasmin $(70 \mathrm{~nm})$ were incubated together for the indicated times, and the remaining intact $\mathrm{A} \beta 1-40$ was quantified. Under these conditions, $\mathrm{A} \beta$ was $75 \%$ cleared within $20 \mathrm{~min}$. From these experiments, we calculated an apparent Kcat of plasmin for nonaggregated $\mathrm{A} \beta$ of $0.48 / \mathrm{sec}$, i.e., one molecule of plasmin cleaves 0.48 molecule of nonaggregated $\mathrm{A} \beta$ per second. This calculation assumes that the A $\beta$ concentration is sufficiently above the $K_{\mathrm{m}}$ so that plasmin is functioning at or near $V_{\text {max }}$; this is likely because the $K_{\mathrm{m}}$ of plasmin for fibrin is $6 \mu \mathrm{M}$, and the $\mathrm{A} \beta$ is present in a 550 -fold excess relative to plasmin. By comparison, the Kcat of nonaggregated fibrin cleavage by plasmin is 7/sec (Kastrikina et al., 1986).

Because $\mathrm{A} \beta$ aggregates accumulate in $\mathrm{AD}$, and because the natural plasmin substrate is aggregated fibrin, we next examined the ability of plasmin to cleave aggregated $\mathrm{A} \beta$. $\mathrm{A} \beta$ was allowed to aggregate by incubating an $\mathrm{A} \beta$ solution $(100 \mu \mathrm{M})$ at $37^{\circ} \mathrm{C}$ for $6 \mathrm{hr}$. thioflavin T (ThT) assays demonstrate that $6 \mathrm{hr}$ is sufficient for maximal aggregation of this $\mathrm{A} \beta$ lot with these conditions (Fig. $4 C$ ). The $\mathrm{A} \beta$ was then diluted to $40 \mu \mathrm{M}$ and incubated in the absence or presence of $0.8 \mu \mathrm{M}$ plasmin for up to $6 \mathrm{hr}$. The quantity of intact $\mathrm{A} \beta$ remaining was then quantified by HPLC (Fig. 4D). Aggregated A $\beta$ was cleared at a much slower rate than nonaggregated $\mathrm{A} \beta$, reaching $\sim 60 \%$ clearance after $6 \mathrm{hr}$ of reaction time. From these experiments, we calculated an apparent Kcat of plasmin for aggregated $\mathrm{A} \beta$ of $0.003 / \mathrm{sec}$. In comparison, plasmin cleaves aggregated fibrin with a Kcat of $0.064 / \mathrm{sec}$ (Kastrikina et al., 1986). Hence, the rate of aggregated $\mathrm{A} \beta$ cleavage is $\sim 1 / 20$ th the rate of cleavage of aggregated fibrin. Interestingly, substrate aggregation reduces the kcat of plasmin $\sim 100$-fold for both fibrin and $\mathrm{A} \beta$.

To gain an understanding of the actions of plasmin on $\mathrm{A} \beta$ aggregates at the ultrastructural level, we performed electron microscopy on aggregated $\mathrm{A} \beta$ before and after plasmin treatment (Fig. 5). Before plasmin treatment, the predominant $\mathrm{A} \beta$ aggregate was a fibril with an approximate diameter of $10 \mathrm{~nm}$, consistent with previous reports regarding synthetic $\mathrm{A} \beta$ fibrils in vitro as well as A $\beta$ fibrils in AD (Roher et al., 1986; Kirschner et al., 1987); very occasional polymers of $A \beta$ with a diameter of $100 \mathrm{~nm}$ were found as well (data not shown), which have also been reported previously in vitro (Stine et al., 1996). After plasmin treatment, although occasional $100 \mathrm{~nm}$ fibrils were still present, the predominant $10 \mathrm{~nm}$ fibrils were much reduced and were replaced with an amorphous deposit that likely reflects dried down $\mathrm{A} \beta$ fragments (Fig. $5 B$ ). Hence, plasmin treatment appears capable of degrading a class of $\mathrm{A} \beta$ fibrils corresponding to the most common fibrils.

\section{The plasmin system and $\mathbf{A} \boldsymbol{\beta}$ neurotoxicity}

Plasmin generated from enhanced tPA activity could contribute to $\mathrm{A} \beta$ neurotoxicity by attacking cell surface proteins, in a manner analogous to how plasmin has been suggested to contribute to neuronal loss in ischemia or excitotoxicity (Chen and Strickland, 1997; Tsirka et al., 1997). Alternatively, because plasmin degrades $\mathrm{A} \beta$, plasmin may block $\mathrm{A} \beta$ toxicity. We evaluated these conflicting hypotheses by comparing $\mathrm{A} \beta$ toxicity in the presence and absence of plasmin. Briefly, rat cortical neurons were treated with (1) plasmin at concentrations as high as $30 \mathrm{nM}$, (2) $\mathrm{A} \beta$ at concentrations that induce moderate $(16 \mu \mathrm{M})$ or high $(25 \mu \mathrm{M})$ levels of toxicity, or (3) both plasmin and A $\beta$. Forty-eight hours later, the neurons were fixed, and subjected to Hoechst 33258 staining to detect chromatin condensation (Fig. 6A,C,E, G,I,K) and DNA endlabeling to detect chromatin fragmentation (Fig. $6 B, D, F, H, J, L)$. These fluorescent micrographs depict representative images of neurons treated with $\mathrm{A} \beta(16$ or $25 \mu \mathrm{M})$ and/or the highest concentration of plasmin $(30 \mathrm{~nm})$. Inspection of these images shows that $\mathrm{A} \beta$ treatment induced frequent chromatin condensation and DNA fragmentation (Fig. 6C-F). Plasmin treatment alone (Fig. 6G,H) was indistinguishable from control cultures (Fig. 6A,B). When neurons were exposed to $\mathrm{A} \beta$ and plasmin, they closely resembled the control cultures (Fig. 6I-L), in sharp contrast to the effects of $\mathrm{A} \beta$ alone. When the frequency of neurons manifesting chromatin condensation was quantified by an observer "blinded" as to cell treatment, plasmin was markedly neuroprotective (Fig. 7). This protection was robust and dependent on the plasmin concentration (Fig. 7). Hence, at plasmin concentrations that are capable of degrading $\mathrm{A} \beta$ and effectively blocking $A \beta$ toxicity, plasmin shows no overt neurotoxicity. We interpret these results as suggesting that plasmin does not contribute to $\mathrm{A} \beta$ toxicity but rather may contribute to $\mathrm{A} \beta$ degradation.

An alternative interpretation of the plasmin neuroprotection is that plasmin acts by removing cell surface receptor proteins suggested to mediate A $\beta$ toxicity, e.g., RAGE (Yan et al., 1996). 


\begin{tabular}{ll}
\hline Table 1. The identity of $\mathbf{A} \boldsymbol{\beta}$ fragments depicted in Figure 3 \\
Peak \# & Cleavage product (in bold) \\
\hline 1 & DAEFRHDSGYEVHHQKLVFFAEDVGSN KGAIIGLM VGGVV \\
2 & DAEFRHDSGYEVHHQKLVFFAEDVGSNKGAIIGLM VGGVV \\
3 & DAEFRHDSGYEVHHQKLVFFAEDVGSNKGAIIGLMVGGVV \\
4 & DAEFRHDSGYEVHHQKLVFFAEDVGSNKGAIIGLMVGGVV \\
5 & DAEFRHDSGYEVHHQKLVFFAEDVGSNKGAIIGLMVGGVV (deaminated E) \\
6 & DAEFRHDSGYEVHHQKLVFFAEDVGSNKGAIIGLMVGGVV \\
7 & DAEFRHDSGYEVHHQKLVFFAEDVGSNKGAIIGLM VGGVV \\
8 & DAEFRHDSGYEVHHQKLVFFAEDVGSNKGAIIGLMVGGVV \\
9 & DAEFRHDSGYEVHHQKLVFFAEDVGSNKGAIIGLMVGGVV
\end{tabular}

The identity of each fragment was determined by mass spectral analysis. The identity of each peak is consistent with the known specificity of plasmin to cleave after basic amino acids. After plasmin digestion, peak 9 actually contained a trace of A $\beta 6-40$ along with $\mathrm{A} \beta 1-40$; in experiments wherein this mixture was resolved by using an exceedingly shallow acetonitrile gradient in the HPLC, the proportion of A $\beta 6-40$ present in this peak was $<1 \%$ after 5, 10, 15, or 20 min of reaction time (data not shown).
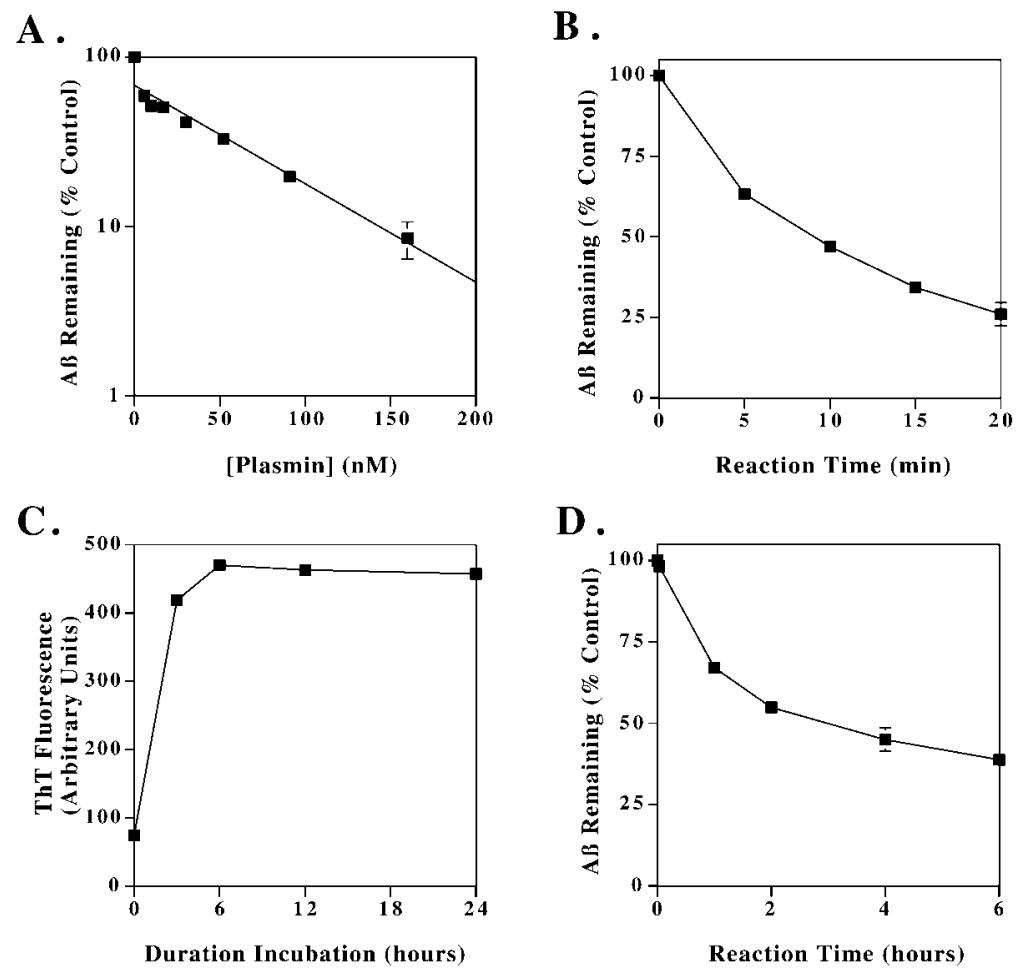

Figure 4. Kinetics of $\mathrm{A} \beta$ degradation by plasmin. Plasmin concentration dependence of $\mathrm{A} \beta$ cleavage $(A) . \mathrm{A} \beta(40 \mu \mathrm{M})$ was incubated with plasmin at the indicated concentrations for 30 min, and the amount of remaining $\mathrm{A} \beta 1-40$ was quantified by HPLC. The data represent the mean \pm range of two separate experiments. Time dependence of plasmin cleavage of $\mathrm{A} \beta(B)$. $\mathrm{A} \beta 1-40(40 \mu \mathrm{M})$ and plasmin $(70 \mathrm{nM})$ were incubated for the indicated times, and the remaining intact $A \beta 1-40$ was quantified. The data represent the mean $\pm \mathrm{SE}, n=4$. Time course of $\mathrm{A} \beta$ aggregation $(C)$. $\mathrm{A} \beta$ solutions $(100 \mu \mathrm{M})$ were incubated at $37^{\circ} \mathrm{C}$ for the indicated times, and changes in aggregation were assessed simultaneously by ThT fluorescence. Time dependence of plasmin degradation of aggregated $\mathrm{A} \beta(D)$. After aggregating for 6 hr at $100 \mu \mathrm{M}, \mathrm{A} \beta$ was diluted to $40 \mu \mathrm{M}$ and incubated in the absence or presence of $70 \mathrm{~nm}$ plasmin for up to $6 \mathrm{hr}$. The quantity of intact $\mathrm{A} \beta$ remaining was then quantified by HPLC. These data represent the mean \pm SE of three independent experiments.
If this were the case, we hypothesized that treating with plasmin before $\mathrm{A} \beta$ would be at least partially protective. To address this possibility, we compared the neuroprotective effects of plasmin when neurons were pretreated with plasmin for $18 \mathrm{hr}$ before $\mathrm{A} \beta$ treatment versus neurons treated with plasmin concurrent with $\mathrm{A} \beta$. As observed previously, $25 \mu \mathrm{M} \mathrm{A} \beta$ caused a marked decline in viability, and concurrent plasmin treatment provided concentration-dependent protection (Fig. 8). In contrast, plasmin treatment before $\mathrm{A} \beta$ afforded no protection. We interpret this observation as supporting the possibility that the neuroprotective effects of plasmin are likely attributable to direct $\mathrm{A} \beta$ degradation.

To evaluate whether the protective effects of plasmin extended to the cytoskeleton, neurons were treated with plasmin, $\mathrm{A} \beta$, or the combination of plasmin and $\mathrm{A} \beta$, and cytoskeletal integrity assessed by neurofilament immunofluorescence (Fig. 9B,D,F,H); chromatin was stained in parallel with Hoechst 33258 (Fig. $9 A, C, E, G)$. Inspection of these images reveals that $\mathrm{A} \beta$ treatment largely ablated neurofilament staining (Fig. $9 C, D$ ) relative to control cultures (Fig. 9A,B). Plasmin treatment alone (Fig. 9E,F) was indistinguishable from control cultures. The neurofilament network of neurons exposed to $\mathrm{A} \beta$ and plasmin was markedly protected from $\mathrm{A} \beta$ toxicity (Fig. 9G,H), closely resembling control cultures. Hence, these results suggest that plasmin has little discernable effect on the cytoskeleton itself and, moreover, maintains cytoskeletal integrity in the presence of $\mathrm{A} \beta$.

\section{DISCUSSION}

The primary findings reported here are threefold. First, $\mathrm{A} \beta$ leads to the induction of tPA and UPA in vitro and in vivo. Second, plasmin degrades nonaggregated $\mathrm{A} \beta$ as well as $\mathrm{A} \beta$ fibrils at rates that are comparable to the rates of plasmin toward its physiological substrate, fibrin. Third, plasmin is effective at blocking $\mathrm{A} \beta$ toxicity in vitro while manifesting little direct neurotoxicity. Hence, these results indicate that $\mathrm{A} \beta$ accumulation leads to the 
Figure 5. Electron microscopy reveals that plasmin clears $10 \mathrm{~nm}$ diameter $\mathrm{A} \beta$ fibrils. Before plasmin treatment, the vast majority of $\mathrm{A} \beta$ fibrils had a diameter of $\sim 10 \mathrm{~nm}(A)$. After plasmin treatment, these fibrils were largely replaced by amorphous deposits that likely reflected dried down $\mathrm{A} \beta$ fragments $(B)$. These results were replicated in two separate $\mathrm{A} \beta$ preparations. Scale bar, $1 \mu \mathrm{m}$.
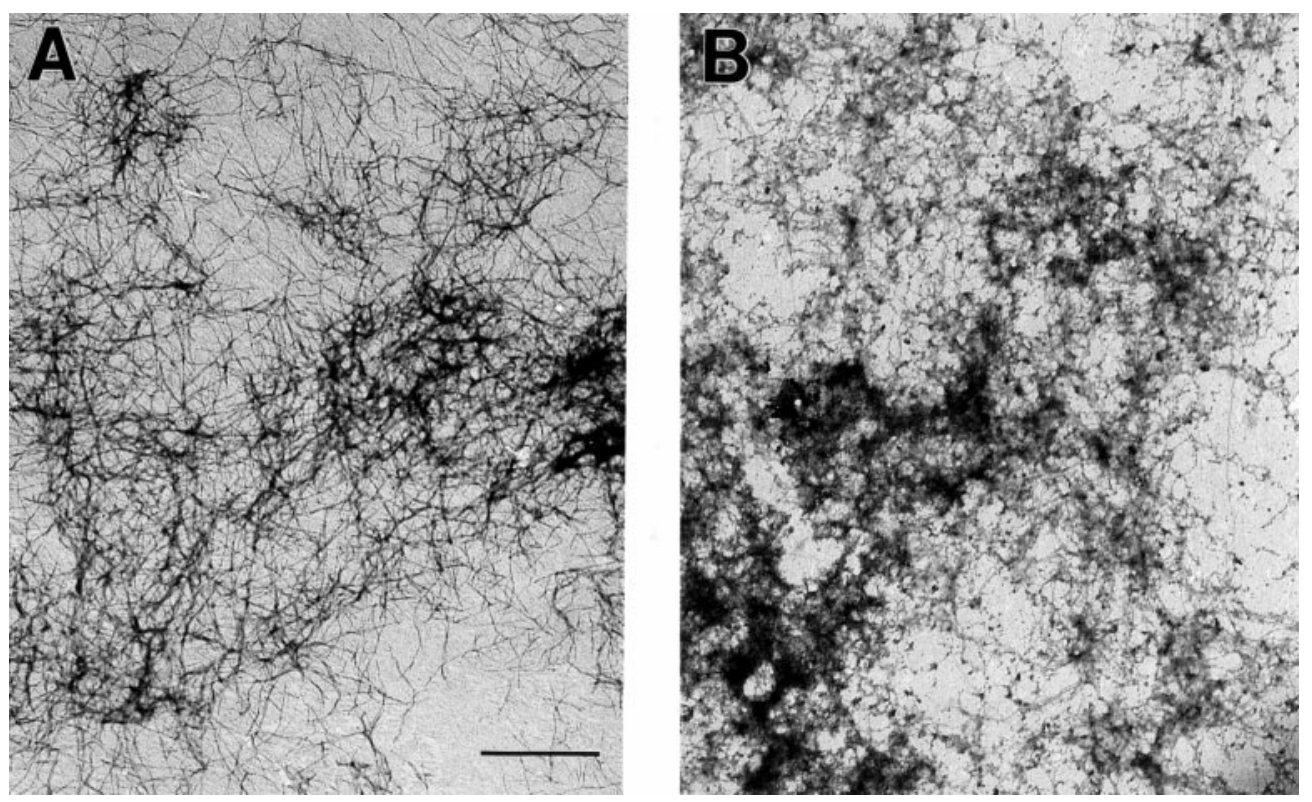

\section{Hoechst 33258}


$6 \mu \mathrm{M} \mathrm{AB}$

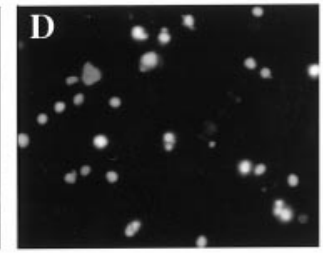

$25 \mu \mathrm{M} \mathrm{AB}$
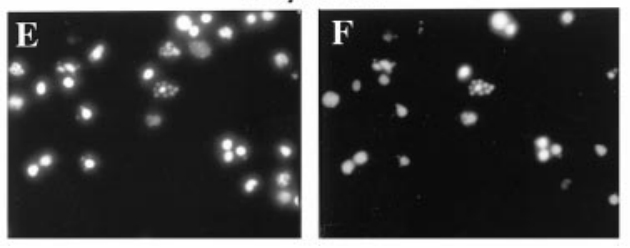

Hoechst

33258
TUNEL

\section{0 nM Plasmin}

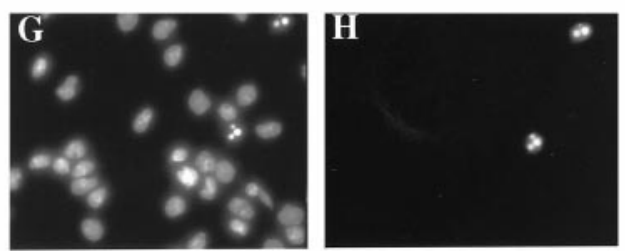

$16 \mu \mathrm{M}$ AB, 30 nM Plasmin


Figure 6. Plasmin effects on $\mathrm{A} \beta$ induced chromatin condensation and fragmentation. Rat cortical neurons were treated with the indicated concentrations of $\mathrm{A} \beta$ for $48 \mathrm{hr}$ in the presence or absence of plasmin $(30 \mathrm{~nm})$. A $\beta$ induced chromatin condensation (Hoechst 33258 staining) and DNA fragmentation (TUNEL staining). These effects were largely reduced in cultures treated with plasmin and $\mathrm{A} \beta$. These results are representative of those obtained in at least six separate neuronal preparations. activation of the plasmin system. In this model, plasmin activation results not in neurotoxicity but rather in protection from $\mathrm{A} \beta$, apparently via $\mathrm{A} \beta$ degradation. Although formal evaluation of this scenario awaits the maturation of mice transgenic for $\mathrm{A} \beta \mathrm{P}$ and wild-type or deficient in tPA, the results presented here are remarkable in that they describe the induction of the plasmin protease system by $\mathrm{A} \beta$ and describe plasmin as the first physiological protease capable of degrading $\mathrm{A} \beta$ aggregates.

Two primary mechanisms of $\mathrm{A} \beta$ clearance have been studied, including receptor-mediated cellular internalization and extracellular proteolysis. In sharp contrast to the attention directed at elucidating the pathways of $\mathrm{A} \beta$ generation (for review, see Selkoe, 1997; Price and Sisodia, 1998), the pathways responsible for $\mathrm{A} \beta$ clearance have received little study until recently. Receptor-mediated cellular internalization has received much interest, because in vitro studies have found that $\mathrm{A} \beta$ may be cleared as a result of its association with either apolipoprotein $\mathrm{E}$ or with $\alpha$-2-macroglobulin (A2M) followed by internalization of the complex via low-density lipoprotein receptor-related protein (LRP) (Narita et al., 1997; Hughes et al., 1998). Alternatively, A $\beta$ may be cleared directly via the scavenger receptor (Paresce et al., 1996). That at least the former pathway may be physiologically significant is supported by recent studies implicating A2M and LRP in FAD (Kang et al., 1997; Blacker et al., 1998). Interestingly, because tPA has also been shown to bind to A2M and subsequently be internalized as a complex via LRP (Bu et al., 




Figure 8. Treating neurons with plasmin before $\mathrm{A} \beta$ does not protect neurons from $A \beta$ toxicity. The frequency of apoptosis in neurons treated with plasmin before or during $\mathrm{A} \beta$ treatment was quantified. These results represent the mean \pm range of two separate neuronal preparations.

1992), genetic studies linking A2M and LRP with AD may be relevant to the plasmin proteolytic cascade as well.

The second proposed mechanism of $\mathrm{A} \beta$ clearance is extracellular proteolysis by resident proteases. Screens for proteases capable of degrading $\mathrm{A} \beta$ have identified a metalloprotease secreted by macrophages (Qiu et al., 1996, 1997) and an unknown serine protease (Mentlein et al., 1998). These proteases were apparently incapable of degrading $\mathrm{A} \beta$ aggregates (Qiu et al., 1996, 1997; Mentlein et al., 1998). These screens likely did not identify the plasmin system because the plasminogen and tPA concentrations in the conditioned medium were insufficient for the necessary bimolecular reaction between tPA and plasminogen. Van Nostrand and Porter (1999) recently reported that plasmin cleaves $\mathrm{A} \beta$ between amino acids 5 and 6 , but did not report the further $\mathrm{A} \beta$ degradation described here or that plasmin degrades $A \beta$ fibrils with physiological efficiency. Indeed, the only protease previously reported as capable of degrading $A \beta$ fibrils is the bacterial protease mixture pronase, which was described as capable of degrading nonaggregated $\mathrm{A} \beta$, aggregated $\mathrm{A} \beta$, and, more slowly, A $\beta$ purified from plaque cores (Tennent et al., 1995). Hence, the identification of plasmin here as a physiologically relevant protease capable of degrading $\mathrm{A} \beta$ aggregates is highly significant.

The results presented and discussed here suggest a possible model for the actions of the plasmin system relative to $\mathrm{A} \beta$, i.e., $\mathrm{A} \beta$ aggregates lead to the activation of a proteolytic cascade that degrades $\mathrm{A} \beta$. More specifically, we propose that $\mathrm{A} \beta$ accumulation upregulates the expression of $t P A$, and that $\mathrm{A} \beta$ then serves as an
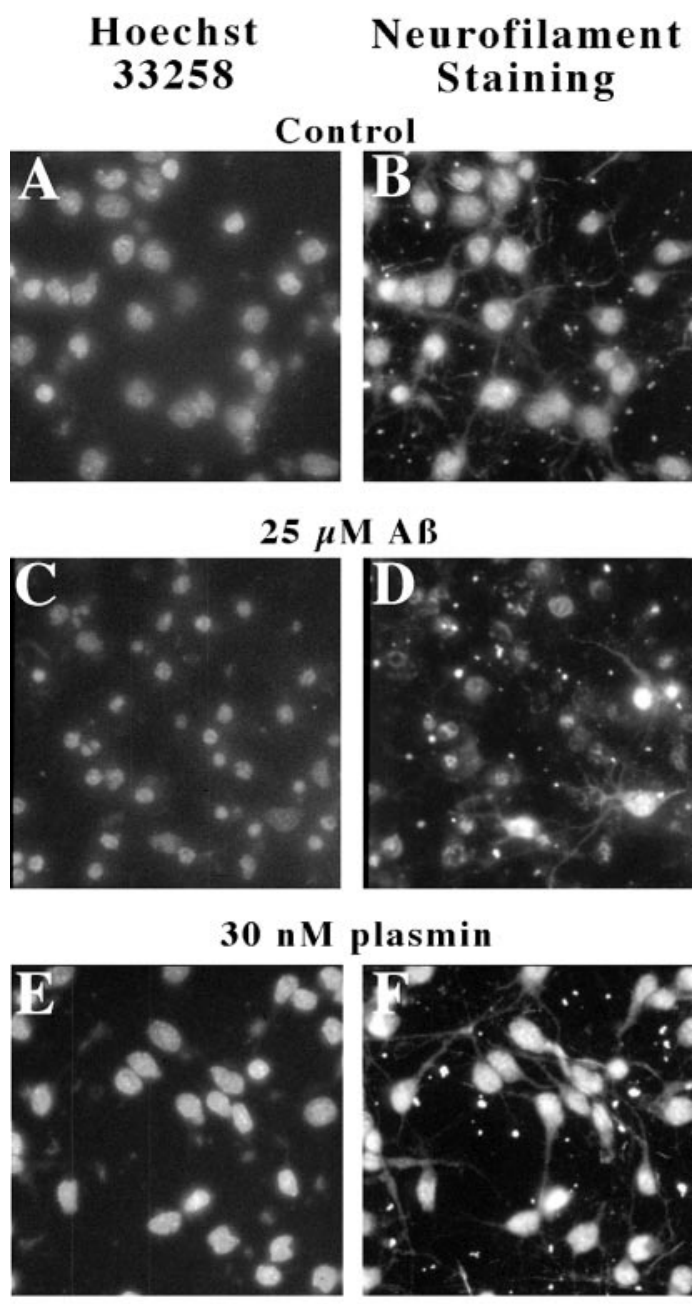

$25 \mu \mathrm{M}$ AB, $30 \mathrm{nM}$ plasmin

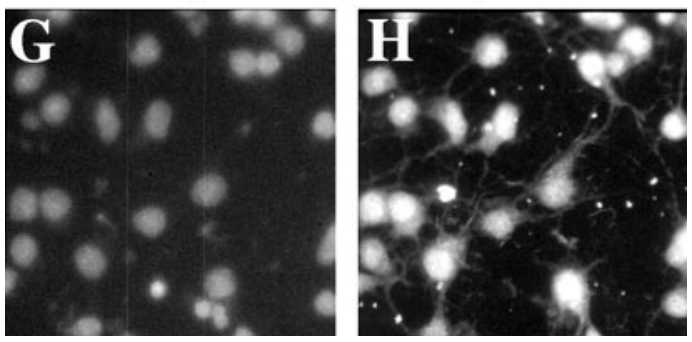

Figure 9. Plasmin treatment maintains neuronal cytoskeleton. Neurons were treated with plasmin, $\mathrm{A} \beta$, or the combination of plasmin and $\mathrm{A} \beta$ as indicated, and cytoskeletal integrity was assessed by neurofilament immunofluorescence; chromatin was stained in parallel with Hoechst 33258. Similar results were obtained in two separate experiments.

activating cofactor for tPA (Kingston et al., 1995; Wnendt et al., 1997) to produce a localized conversion of plasminogen to the active protease, plasmin. Plasmin then cleaves $\mathrm{A} \beta$ with physiological efficiency, protecting neurons from any deleterious actions of $\mathrm{A} \beta$ in the process. Interestingly, PAI-1, the principal physiological inhibitor of tPA, as well as the less prominent PAI-2, are both increased during inflammation (Henkin et al., 1991) and have both been reported to be increased in AD (Akiyama et al., 1993; Sutton et al., 1994). Hence, we interpret these results as suggesting a feedforward model in AD in which inflammation increases the expression of the plasminogen activator inhibitors, 


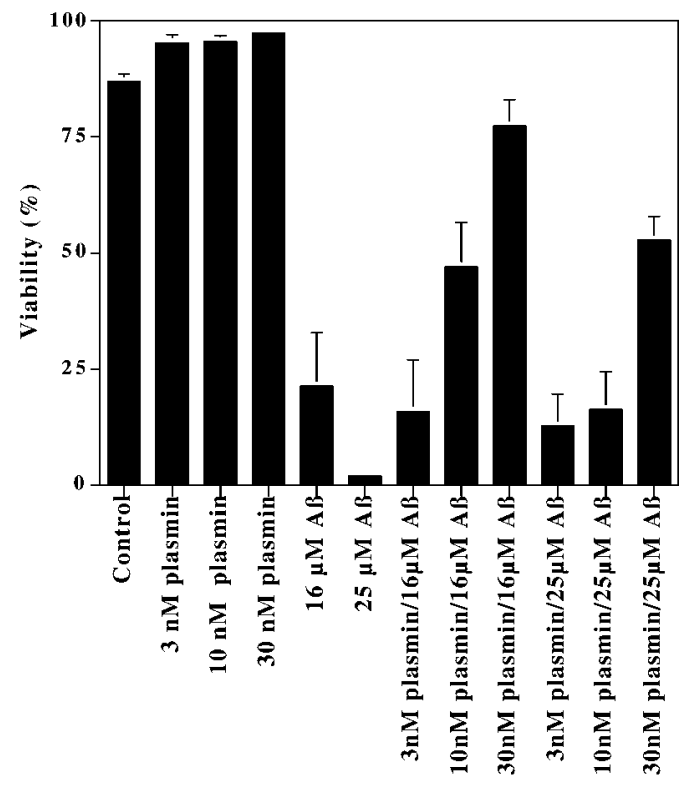

Figure 7. Plasmin protects neurons from $\mathrm{A} \beta$ toxicity. Neurons were treated with $\mathrm{A} \beta$, plasmin, or the indicated combinations of $\mathrm{A} \beta$ and plasmin for $48 \mathrm{hr}$. The cultures were then fixed and analyzed for the frequency of apoptosis by an observer "blinded" as to cell treatment. There is a clear trend for the concentration-dependent ability of plasmin to protect neurons from $A \beta$ toxicity. These protective effects reached statistical significance $(p<0.05)$ for the $16 \mu \mathrm{M} \mathrm{A} \beta$ samples treated with 10 and $30 \mathrm{~nm}$ plasmin and for the $25 \mu \mathrm{M} \mathrm{A} \beta$ samples treated with $30 \mathrm{nM}$ plasmin. At least 250 neurons were scored for each treatment. These results represent the mean $\pm \mathrm{SE}$ of at least four separate $\mathrm{A} \beta$ treatments.

which in turn inhibit tPA, thereby reducing plasmin activity, and allowing $A \beta$ levels to increase, which may then fuel further inflammation. In ongoing experiments, we are performing a critical test of this hypothesis, i.e., quantifying $\mathrm{A} \beta$ levels in mice overexpressing $\mathrm{A} \beta$ and lacking tPA. Hence, the work presented here, in conjunction with that previously in the literature, supports a "testable" hypothesis that the plasmin system regulates $\mathrm{A} \beta$ levels.

Mice with deficiencies in the plasmin system have been used to assess the role of the plasmin system in the CNS. Mice deficient in tPA, uPA, or PAI-1 develop with only modest deficits, whereas mice deficient in plasminogen develop and reproduce normally but suffer from thrombotic emboli and typically die by 6 months of age (for review, see Carmeliet et al., 1995). Although such mice have been used to implicate the plasminogen system as contributing to neuronal loss in ischemia or excitoxicity models (Chen and Strickland, 1997; Tsirka et al., 1997; Wang et al., 1998), other reports have suggested that tPA may be either nontoxic or directly neuroprotective (Tsirka et al., 1996; Kim et al., 1999). Additional events may occur in ischemia or excitotoxicity that enhance susceptibility to plasmin-mediated neuronal loss. For example, plasmin activates extracellular matrix metalloproteases (Lijnen et al., 1998), and matrix degradation can modulate apoptosis (Basbaum and Werb, 1996; Romanic et al., 1998). Interestingly, we observe here that $\mathrm{A} \beta$ induces timp1 expression, which we speculate may minimize matrix degradation in response to $\mathrm{A} \beta$.

In summary, we interpret the data presented here as supporting the hypothesis that the plasmin system may contribute to the regulation of $A \beta$ levels and actions. One potential ramification of this work is that plasmin or a related recombinant protease might be used to clear amyloid deposits in vivo. That amyloid deposits may be cleared naturally in vivo is supported by observations that amyloid resulting from systemic amyloidoses regresses slowly if amyloid production is inhibited (Holmgren et al., 1993) and that pre-existing $\mathrm{A} \beta$ deposits can be reduced by subsequent " $\mathrm{A} \beta$ vaccination" in a mouse model of $\mathrm{A} \beta$ accumulation (Schenk et al., 1999). Hence, these results suggest that amyloid deposits may be amenable to clearance. If $\mathrm{A} \beta$ clearance proves to ameliorate $\mathrm{AD}$, proteases such as the plasmin system described here may contribute to disease treatment.

\section{REFERENCES}

Akiyama H, Ikeda K, Kondo H, Kato M, McGeer PL (1993) Microglia express the type 2 plasminogen activator inhibitor in the brain of control subjects and patients with Alzheimer's disease. Neurosci Lett 164:233-235.

Arts J, Herr I, Lansink M, Angel P, Kooistra T (1997) Cell-type specific DNA-protein interactions at the tissue-type plasminogen activator promoter in human endothelial and HeLa cells in vivo and in vitro. Nucleic Acids Res 25:311-317.

Basbaum CB, Werb Z (1996) Focalized proteolysis: spatial and temporal regulation of extracellular matrix degradation at the cell surface. Curr Opin Cell Biol 8:731-738.

Blacker D, Wilcox MA, Laird NM, Rodes L, Horvath SM, Go RC, Perry R, Watson BJ, Bassett SS, McInnis MG, Albert MS, Hyman BT, Tanzi RE (1998) Alpha-2 macroglobulin is genetically associated with Alzheimer disease. Nat Genet 19:357-360.

Brewer GJ, Torricelli JR, Evege EK, Price PJ (1993) Optimized survival of hippocampal neurons in B27-supplemented Neurobasal, a new serum-free medium combination. J Neurosci Res 35:567-576.

Bu G, Williams S, Strickland DK, Schwartz AL (1992) Low density lipoprotein receptor-related protein/alpha 2-macroglobulin receptor is an hepatic receptor for tissue-type plasminogen activator. Proc Natl Acad Sci USA 89:7427-7431.

Carmeliet P, Bouche A, De Clercq C, Janssen S, Pollefeyt S, Wyns S, Mulligan RC, Collen D (1995) Biological effects of disruption of the tissue-type plasminogen activator, urokinase-type plasminogen activator, and plasminogen activator inhibitor-1 genes in mice. Ann NY Acad Sci 748:367-381.

Chen ZL, Strickland S (1997) Neuronal death in the hippocampus is promoted by plasmin-catalyzed degradation of laminin. Cell 91:917-925.

Chomczynski P, Sacchi N (1987) Single-step method of RNA isolation by acid guanidinium thiocynate-phenol-chloroform extraction. Anal Biochem 162:156-159.

Deb S, Gottschall PE (1996) Increased production of matrix metalloproteinases in enriched astrocyte and mixed hippocampal cultures treated with beta-amyloid peptides. J Neurochem 66:1641-1647.

Estus S (1997) Optimization and validation of RT-PCR as a tool to analyze apoptotic gene expression. In: NeuroMethods 29: apoptosis techniques and protocols (Poirier J, ed), pp 67-84. Totowa, NJ: Humana.

Estus S, Tucker HM, van Rooyen C, Wright S, Brigham E, Wogulis M, Rydel R (1997) Aggregated amyloid- $\beta$ protein induces cortical neuronal apoptosis and concomitant "apoptotic" pattern of gene induction. J Neurosci 17:7736-7745.

Henkin J, Marcotte P, Yang HC (1991) The plasminogen-plasmin system. Prog Cardiovasc Dis 34:135-164.

Holmgren G, Ericzon BG, Groth CG, Steen L, Suhr O, Andersen O, Wallin BG, Seymour A, Richardson S, Hawkins PN, Pepys MB (1993) Clinical improvement and amyloid regression after liver transplantation in hereditary transthyretin amyloidosis. Lancet 341:1113-1116.

Hsiao K, Chapman P, Nilsen S, Eckman C, Harigaya Y, Younkin S, Yang F, Cole G (1996) Correlative memory deficits, A $\beta$ elevation, and amyloid plaques in transgenic mice. Science 274:99-102.

Hughes SR, Khorkova O, Goyal S, Knaeblein J, Heroux J, Riedel NG, Sahasrabudhe S (1998) Alpha2-macroglobulin associates with betaamyloid peptide and prevents fibril formation. Proc Natl Acad Sci USA 95:3275-3280.

Kang DE, Saitoh T, Chen X, Xia Y, Masliah E, Hansen LA, Thomas RG, Thal LJ, Katzman R (1997) Genetic association of the low-density lipoprotein receptor-related protein gene (LRP), an apolipoprotein E receptor, with late-onset Alzheimer's disease. Neurology 49:56-61.

Kastrikina TF, Taran LD, Kudinov SA (1986) Kinetic characteristics of 
fibrinogen and fibrin hydrolysis by plasmin 1 and 2 and miniplasmin. Thromb Res 41:681-688.

Kim YH, Park JH, Hong SH, Koh JY (1999) Nonproteolytic neuroprotection by human recombinant tissue plasminogen activator. Science 284:647-650.

Kingston IB, Castro MJ, Anderson S (1995) In vitro stimulation of tissue-type plasminogen activator by Alzheimer amyloid beta-peptide analogues. Nat Med 1:138-142.

Kirschner DA, Inouye H, Duffy LK, Sinclair A, Lind M, Selkoe DJ (1987) Synthetic peptide homologous to beta protein from Alzheimer disease forms amyloid-like fibrils in vitro. Proc Natl Acad Sci USA 84:6953-6957.

Kwaan HC (1992) The plasminogen-plasmin system in malignancy. Cancer Metastasis Rev 11:291-311.

Lijnen HR, Silence J, Lemmens G, Frederix L, Collen D (1998) Regulation of gelatinase activity in mice with targeted inactivation of components of the plasminogen/plasmin system. Thromb Haemost 79:1171-1176.

Littell RC, Milliken GA, Stroup WW, Wolfsinger RD (1996) SAS system for mixed models. Cary, NC: SAS.

Mentlein R, Ludwig R, Martensen I (1998) Proteolytic degradation of Alzheimer's disease amyloid beta-peptide by a metalloproteinase from microglia cells. J Neurochem 70:721-726.

Narita M, Holtzman DM, Schwartz AL, Bu G (1997) Alpha2macroglobulin complexes with and mediates the endocytosis of betaamyloid peptide via cell surface low-density lipoprotein receptorrelated protein. J Neurochem 69:1904-1911.

Paresce DM, Ghosh RN, Maxfield FR (1996) Microglial cells internalize aggregates of the Alzheimer's disease amyloid beta-protein via a scavenger receptor. Neuron 17:553-565.

Pike C, Walencewicz A, Glabe C, Cotman C (1991) In vitro aging of $\beta$-amyloid protein causes peptide aggregation and neurotoxicity. Brain Res 563:311-314.

Price DL, Sisodia SS (1998) Mutant genes in familial Alzheimer's disease and transgenic models. Annu Rev Neurosci 21:479-505.

Qiu WQ, Borth W, Ye Z, Haass C, Teplow DB, Selkoe DJ (1996) Degradation of amyloid beta-protein by a serine protease-alpha2macroglobulin complex. J Biol Chem 271:8443-8451.

Qiu WQ, Ye Z, Kholodenko D, Seubert P, Selkoe DJ (1997) Degradation of amyloid beta-protein by a metalloprotease secreted by microglia and other neural and non-neural cells. J Biol Chem 272:6641-6646.

Reuning U, Magdolen V, Wilhelm O, Fischer K, Lutz V, Graeff H, Schmitt M (1998) Multifunctional potential of the plasminogen activation system in tumor invasion and metastasis [review]. Int J Oncol 13:893-906.

Roher A, Wolfe D, Palutke M, KuKuruga D (1986) Purification, ultrastructure, and chemical analysis of Alzheimer disease amyloid plaque core protein. Proc Natl Acad Sci USA 83:2662-2666.

Romanic AM, White RF, Arleth AJ, Ohlstein EH, Barone FC (1998) Matrix metalloproteinase expression increases after cerebral focal isch- emia in rats: inhibition of matric metalloproteinase-9 reduces infarct size. Stroke 29:1020-1030.

Schenk D, Barbour R, Dunn W, Gordon G, Grajeda H, Guido T, Hu K, Huang J, Johnson-Wood K, Khan K, Kholodenko D, Lee M, Liao Z, Lieberburg I, Motter R, Mutter L, Soriano F, Shopp G, Vasquez N, Vandevert C, Walker S, Wogulis M, Yednock T, Games D, Seubert P (1999) Immunization with amyloid-beta attenuates Alzheimerdisease-like pathology in the PDAPP mouse. Nature 400:173-177.

Selkoe DJ (1997) Alzheimer's disease: genotypes, phenotype, and treatments. Science 275:630-631.

Simmons LK, May PC, Tomaselli KJ, Rydel RE, Fuson KS, Brigham EF, Wright S, Lieberburg I, Becker GW, Brems DN (1994) Secondary structure of amyloid beta peptide correlates with neurotoxic activity in vitro. Mol Pharmacol 45:373-379.

Stine WBJ, Snyder SW, Ladror US, Wade WS, Miller MF, Perun TJ, Holzman TF, Krafft GA (1996) The nanometer-scale structure of amyloid-beta visualized by atomic force microscopy. J Protein Chem 15:193-203.

Sutton R, Keohane ME, VanderBerg SR, Gonias SL (1994) Plasminogen activator inhibitor-1 in the cerebrospinal fluid as an index of neurological disease. Blood Coagul Fibrinolysis 5:167-171.

Tennent GA, Lovat LB, Pepys MB (1995) Serum amyloid P component prevents proteolysis of the amyloid fibrils of Alzheimer's disease and systemic amyloidosis. Proc Natl Acad Sci USA 92:4299-4303.

Tsirka SE, Rogove AD, Strickland S (1996) Neuronal cell death and tPA. Nature 384:123-124.

Tsirka SE, Rogove AD, Bugge TH, Degen JL, Strickland S (1997) An extracellular proteolytic cascade promotes neuronal degeneration in the mouse hippocampus. J Neurosci 17:543-552.

Tucker HM, Mottonen J, Goldsmith EJ, Gerard RD (1995) Engineering of plasminogen activator inhibitor-1 to reduce the rate of latency transition. Nat Struct Biol 2:442-445.

Van Nostrand WE, Porter M (1999) Plasmin cleavage of the amyloid beta-protein: alteration of secondary structure and stimulation of tissue plasminogen activator activity. Biochemistry 38:11570-11576.

Vijayaragahaven J, Tucker M, Fehrentz JA, Isbell D, Hersh LB (1995) Reaction of neprilysin (neutral endopeptidase) and thermolysin with cyclic peptides. Arch Biochem Biophys 322:405-409.

Wang YF, Tsirka SE, Strickland S, Stieg PE, Soriano SG, Lipton SA (1998) Tissue plasminogen activator (tPA) increases neuronal damage after focal cerebral ischemia in wild-type and tPA-deficient mice. Nat Med 4:228-231.

Wnendt S, Wetzels I, Gunzler WA (1997) Amyloid beta peptides stimulate tissue-type plasminogen activator but not recombinant prourokinase. Thromb Res 85:217-224.

Yan SD, Chen X, Fu J, Chen M, Zhu H, Roher A, Slattery T, Zhao L, Nagashima M, Morser J, Migheli A, Nawroth P, Stern D, Schmidt AM (1996) RAGE and amyloid-beta peptide neurotoxicity in Alzheimer's disease. Nature 382:685-691. 